\title{
A new Pseudophoxinus (Teleostei, Cyprinidae) species from Southwestern Anatolia, with remarks on the distribution of the genus in western Anatolia
}

\author{
Fahrettin Küçük1,†, İskender Gülle ${ }^{2, \ddagger}$, S. Serkan Güçlü̈,\$, \\ Yilmaz Çiftçỉ, ${ }^{3, \mid}$ Ömer Erdoğan ${ }^{1, \pi}$
}

I Süleyman Demirel University, Eğirdir Fisheries Faculty, Isparta-Turkey 2 Mehmet Akif Ersoy University, Faculty of Science and Literature, Biology Department, Burdur-Turkey 3 Ordu University, Fatsa Marine Science Faculty, Fatsa-Ordu-Turkey

† http://zoobank.org/50084B6D-BEF2-4953-B39B-D618AC621473

¥ http://zoobank.org/D0AOB5E8-DF8E-4775-B4E5-84EDC2F4BE5F

§ http://zoobank.org/8198016F-FCF4-4582-91F9-F0E98C5DF567

| http://zoobank.org/20F86C78-9771-422A-948A-424B0BEBABAB

I http://zoobank.org/2A9040D4-682F-4F55-8F83-401B2B17929E

Corresponding author: Fahrettin Kǚ̧ük (fahrettinkucuk@sdu.edu.tr)

Academic editor: N. Bogutskaya | Received 4 December 2012 | Accepted 24 June 2013 | Published 31 July 2013

http://zoobank.org/E1297225-20A1-4814-A0C3-E1CA82A253AE

Citation: Küçük F, Gülle İ, Güçlü SS, Çiftçi Y, Erdoğan Ö (2013) A new Pseudophoxinus (Teleostei, Cyprinidae) species from Southwestern Anatolia, with remarks on the distribution of the genus in western Anatolia. ZooKeys 320: $29-41$. doi: $10.3897 /$ zookeys.320.4447

\begin{abstract}
Pseudophoxinus burduricus sp. $\mathbf{n}$. is described from drainages of Salda and Burdur lakes, southwestern Turkey. It is distinguished from other Anatolian Pseudophoxinus by a combination of characters: lateral line incomplete, with 21-39 (commonly 26-37) perforated scales and 47-57+1-2 scales in lateral series; $10^{1 / 2}-12 \frac{1}{2}$ scale rows between lateral line and dorsal fin origin, 3-4(5) scale rows between lateral line and the pelvic fin origin; dorsal fin commonly with $71 / 2$ branched rays; anal fin commonly with $61 / 2$ branched rays; 7-8(9) gill rakers on the first branchial arch; a faint and diffuse epidermal black stripe from eye to caudal fin base in alive and preserved individuals; mouth slightly subterminal, tip of mouth cleft on about level of lower margin of eye; snout rounded, its length greater than eye diameter. Comparison is given with all Pseudophoxinus species from western Anatolia.
\end{abstract}

Copyright Fahrettin Küçük et al. This is an open access article distributed under the terms of the Creative Commons Attribution License 3.0 (CC-BY), which permits unrestricted use, distribution, and reproduction in any medium, provided the original author and source are credited. 


\section{Keywords}

Western Anatolia, Cyprinidae, Taxonomy, Pseudophoxinus, new species

\section{Introduction}

According to Perea et al. (2010), there are 14 distinct clades within Leuciscinae of inner waters across the Mediterranean Region, 9 of which being represented in Anatolia. Among these, phylogenies of the genera Petroleuciscus and Pseudophoxinus are most debated; indeed even taxonomic status of some Pseudophoxinus species is uncertain. Two well-defined monophyletic clades represent Anatolian Pseudophoxinus species: first of these corresponds to Central Anatolian species complex including $P$. alii, P. anatolicus, P. antalyae, P. battalgilae, P. crassus, P. elizavetae, P. evliyae, P. fahrettini, P. ninae, and a probable undescribed species; while the other includes Levantine taxa, namely $P$. firati, P. kervillei, P. zeregi and P. zekayi (Perea et al. 2010). Speciation in Pseudophoxinus is heterogenous, as mentioned by Hrbek et al. (2004) and Bogutskaya et al. (2007), and discrepancies between morphological and molecular relationships can be seen (Perea et al. 2010). Separation of the Pseudophoxinus taxa in Anatolia and western Asia into two groups by Bogutskaya et al. (2007), according to a comparison of morphological parameters (sensory pores, scales and their arrangement on the body, vertebral counts, and supraethmoid bone) with that of the type species P. zeregi is another example of the high degree of variability in the genus.

Morphological and phylogenetic distinctness of P. egridiri (Hrbek et al. 2004: 305), and its closeness to the Pelasgus-Delminichthys lineage (Perea et al. 2010) brings some doubts about monophyly of the Anatolian Pseudophoxinus taxa.

As stated by Hrbek et al. (2002, 2004), Anatolia is an important diversification center for the genus Pseudophoxinus which shows allopatric speciation especially in basins of Bey Dağları, Büyük Menderes, Tuz Lake and Lakes District. However, the complex taxonomy of the genus in these basins is still unresolved. Although including several lakes and springs of Lakes Region (Lake Salda, Karapınar Spring near Yeşilova district, Düğer Spring, Lake Bahçeözü, Sazak Spring and Kırkpınar Springs) in the distribution area of $P$. maeandri, Bogutskaya (1992) mentioned that $P$. maeandri populations from Upper Büyük Menderes basin (Lake Işıklı and Düden Spring near Dinar) morphologically differed from remaining populations in having larger scales and shorter lateral line, fewer lateral series scales and gill rakers on the first branchial arch, as well as fewer vertebrae.

According to molecular data presented by Hrbek et al. (2004) Kırkpınar (Lake Söğüt source, Korkuteli) and Avlan source (Elmalı) populations were clearly separated from those in the basins of the lakes Salda and Burdur. Freyhof and Özulug (2009) identified populations of Kırkpınar as a new species, P. evliyae, and populations of Lake Salda and Lake Burdur basin as P. ninae. Perea et al. (2010) did not examine any material from either the type locality (Onaç Stream-Bucak) or other known localities of $P$. ninae (Kestel Swamp-Bucak, Düğer Spring, Lake Karataş and Sazak Spring) and used only mitochondrial and nuclear DNA markers of Lake Salda specimens as representatives of $P$. ninae. 


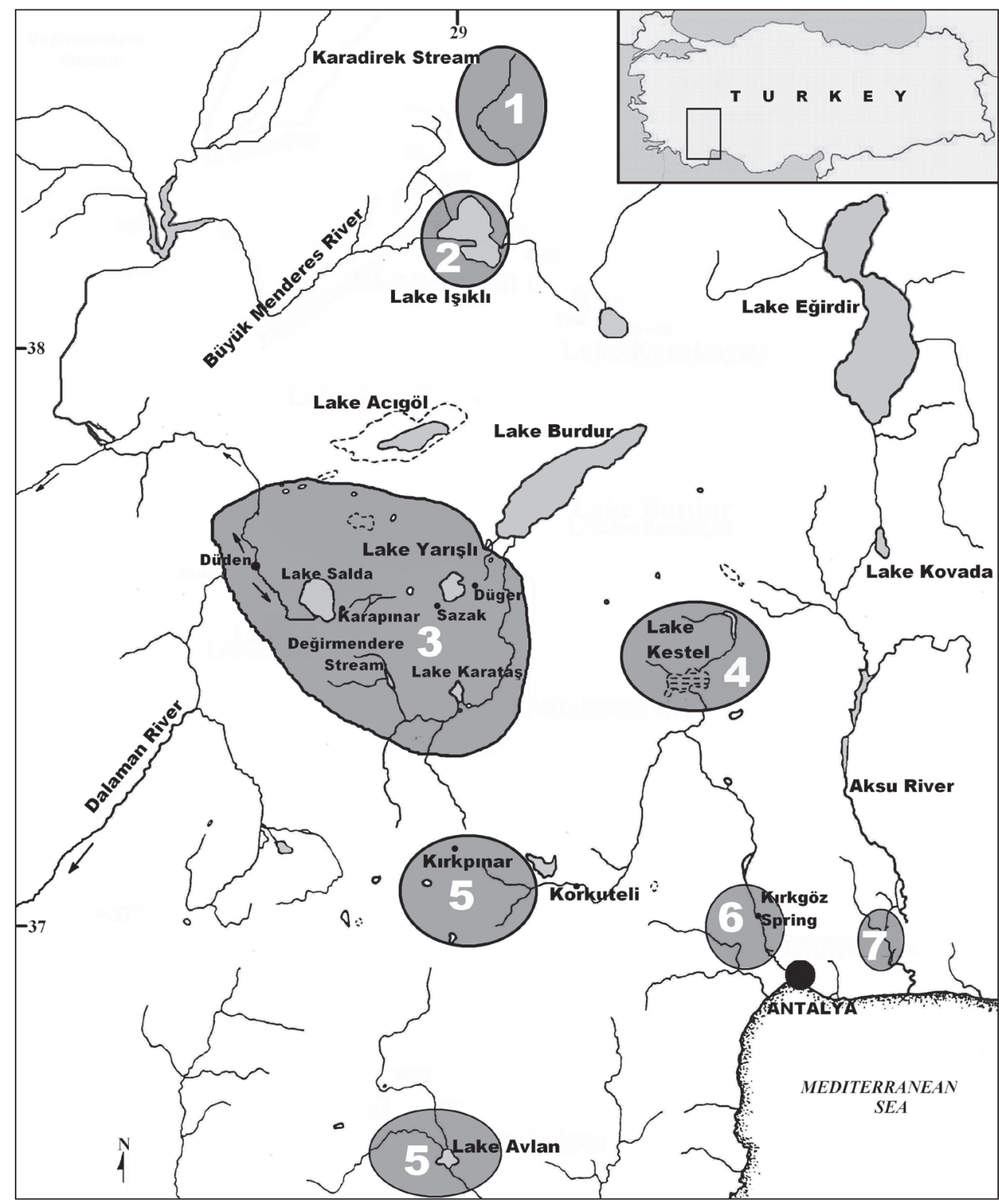

Figure I. Map showing localities of Pseudophoxinus species in western Anatolial P. maeandricus 2 P. maeandri 3 P.burduricus sp. n. 4 P. ninae 5 P. evliyae 6 P. antalyae 7 P. alii

Thus, it was not possible to explain diversification of Pseudophoxinus in southwestern Anatolia (Fig.1) in its entirety. Furthermore, since its description by Ladiges (1960), sufficient information on distribution and taxonomy of $P$. maeandricus has not been given up to date. With regard to the above mentioned morphological and molecular data, it became apparent that the taxonomic position of Pseudophoxinus populations in Burdur and Salda lake basins needed clarification and this led to the present study. 


\section{Materials and methods}

Fish specimens were caught by pulsed DC electrofishing equipment and killed by over anaesthetization, preserved in 5\% formalin. Material is deposited in: IFC-ESUF, Inland Fishes Collection, Eğirdir Fisheries Faculty of Süleyman Demirel University. Counts and measurements follow Kottelat and Freyhof (2007), all measurements being point to point made with a digital calliper $(0.01 \mathrm{~mm}$ sensitive). Standard length (SL) was measured from the tip of the upper lip to the end of the hypural complex. The length of the caudal peduncle was measured from behind the base of the last anal fin ray to the end of the hypural complex, at mid-height of the caudal fin base. Lateral line scales are counted from the anteriormost scale (the first one to touch the shoulder girdle) to the posteriormost one. Scales in lateral series are counted along the midlateral line from the first one to touch the shoulder girdle to the last scale at the end of the hypural complex. Scales on the caudal fin itself are indicated by "+" (Freyhof and Özuluğ 2009). The last two branched dorsal and anal fin rays articulating on a single pterygiophore were counted as $1 \frac{112}{2}$. Vertebral counts were obtained from radiographs and counted as total, predorsal, abdominal and caudal vertebrae following Naseka (1996). Abdominal vertebrae were counted from the first Weberian vertebra to the one just anterior the first caudal vertebra. The first caudal vertebra is that with its haemal spine fully developed. The count of total and caudal vertebrae includes the last complex vertebra bearing hypurals. Osteological characters were examined in cleared and stained with alizarin Red-S specimens and from radiographs (Bogutskaya 1996).

The morphometric characters of the two species of Pseudophoxinus from Turkey were compared by Principal Component Analysis (PCA) using a covariance matrix on $\log$-transformed measurements and counts with the software package PAST version 1.8 (Hammer et al. 2001).

Abbreviations. CSO, supraorbital canal; $\mathrm{CIO}$, infraorbital canal; CPM, preoperculo-mandibular canal; HL, lateral head length; SL, standard length. IFC-ESUF, Inland Fishes Collection, Eğirdir Fisheries Faculty of Süleyman Demirel University, Turkey. IUSHM, Istanbul University, Science Faculty, Hydrobiology Museum, Istanbul.

\section{Results}

Pseudophoxinus burduricus sp. $\mathrm{n}$.

http://zoobank.org/5734C2B8-1D58-40E4-ABD6-43A9C610B1AB

http://species-id.net/wiki/Pseudophoxinus_burduricus

Figures 2, 3

Holotype. IFC-ESUF 0427, female, $62.80 \mathrm{~mm}$ SL; Turkey, Burdur Prov., Değirmendere Creek, Karamanlı, Lake Burdur drainage; 37²4'18"N, 2949'06"E, 07 November 2009, coll. F. Küçük, İ. Gülle and Ö. Erdoğan. 


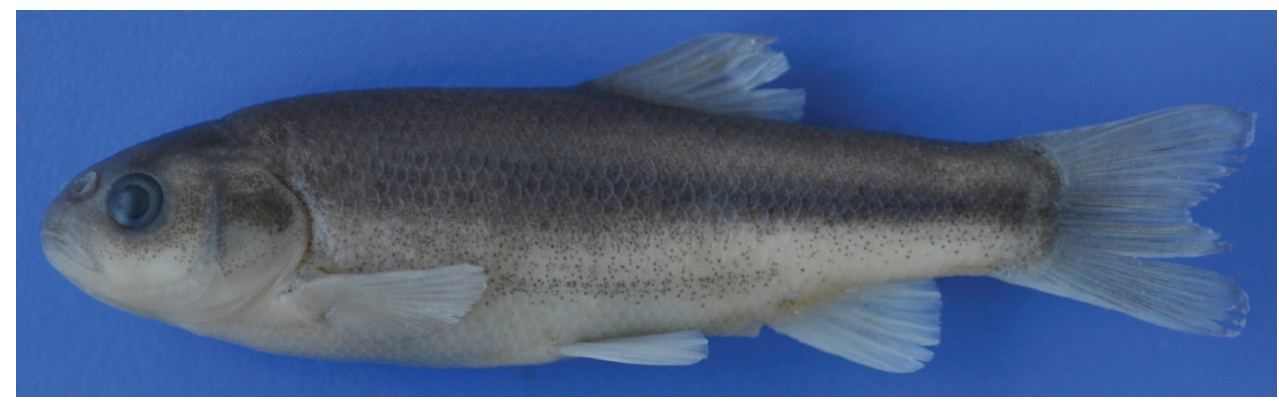

Figure 2. P. burduricus sp. n. IFC-ESUF 0427, holotype, $62.80 \mathrm{~mm} \mathrm{SL}$, female; Turkey: Değirmendere Creek, Burdur.

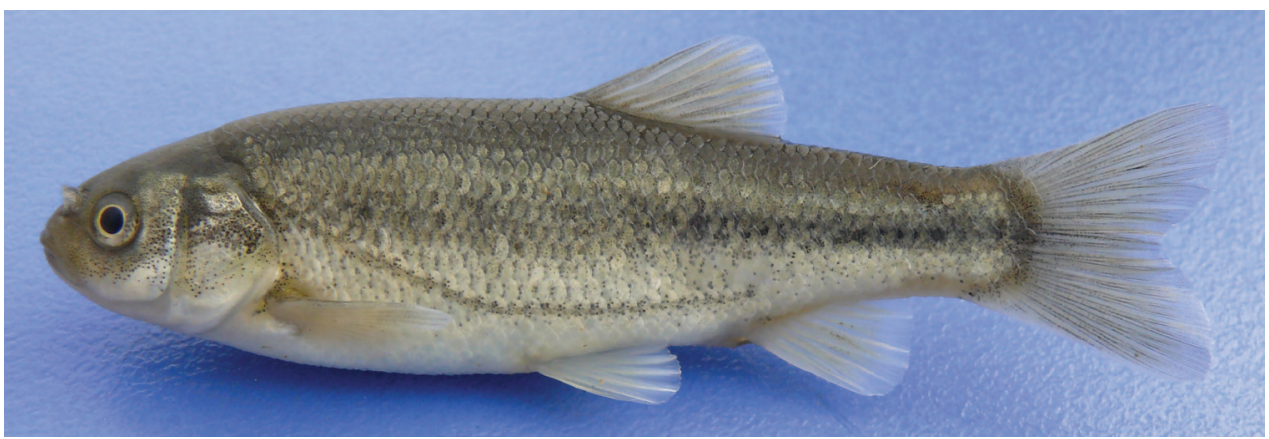

Figure 3. $P$. burduricus sp. n. IFC-ESUF 0428, paratype, $65.82 \mathrm{~mm} \mathrm{SL}$, female; Turkey: Değirmendere Creek, Burdur.

Paratypes. IFC-ESUF 0428, 17 (11 males, 6 females), 39.90-86.69 mm SL; same as holotype.

Additional material. IFC-ESUF 0236, 7, 45.31-54.40 mm SL; Burdur Prov., Salda Stream near Lake Salda; F. Küçük, M.A. Atalay, 13 June 1998. -IFC-ESUF 0289, 3, 31.98-71.56 mm SL, Burdur Prov., Düğer Spring; F. Küçük, A. Altun, M. Telli, 05 August 2006. -IFC-ESUF 0429, 5, 51.34-80.08 mm SL, Burdur Prov., Sazak Spring near Lake Yarışli; F. Küçük, İ. Gülle, S.S. Güçlü, 13 July 2009.- IFCESUF 0430, 6, 41.91-55.95 mm SL, Burdur Prov., Salda Stream near Lake Salda; F. Küçük, İ. Gülle, S.S. Güçlü, 13 December 2009. -IFC-ESUF 0449, 8, 46.10-60.43 mm SL, Burdur Prov.; Salda Stream near Lake Salda; F. Küçük, İ. Gülle, 16 April 2010. -IFC-ESUF 0475, 7, 46.10-60.43 mm SL, Burdur Prov.; Dereköy Stream; F. Küçük, İ. Gülle, S.S. Güçlü. 18 May 2012.

Diagnosis. Pseudophoxinus burduricus is distinguished from all other species of Anatolian Pseudophoxinus by the following unique combination of characters: head short, its length equal or slightly greater than body depth at dorsal fin origin; mouth slightly subterminal, the tip of the mouth cleft on approximately level of with lower margin of eye; snout rounded, its length greater than eye diameter; a faint and diffuse epidermal black stripe from eye to caudal fin base in alive and preserved individuals; 
Table I. Morphometry of $P$. burduricus sp.n. (holotype IFC-ESUF 427, paratypes IFC-ESUF 428, n=17) and $P$. ninae (IFC-ESUF 263, $\mathrm{n}=15$ ).

\begin{tabular}{l|c|c|c}
\hline \multirow{2}{*}{} & \multicolumn{2}{|c|}{ P. burduricus } & P. ninae \\
\cline { 2 - 4 } & Holotype & Paratypes & \\
\hline In percent of standard length & & & \\
\hline Head length & 26.9 & $25.7-27.8(26.8) \pm 0.6$ & $27.1-30.7(28.6) \pm 1.0$ \\
\hline Body depth of dorsal fin origin & 26.6 & $24.1-27.1(25.7) \pm 0.7$ & $27.8-32.1(29.3) \pm 1.2$ \\
\hline Predorsal distance & 56.6 & $51.6-57.4(55.0) \pm 1.7$ & $56.6-60.9(58.0) \pm 1.1$ \\
\hline Prepelvic distance & 72.4 & $50.4-54.7(52.6) \pm 1.5$ & $53.9-56.7(55.7) \pm 0.9$ \\
\hline Preanal distance & 48.4 & $43.0-74.0(72.0) \pm 1.5$ & $72.6-76.5(74.5) \pm 1.1$ \\
\hline Distance between pectoral and anal-fin origins & 26.7 & $24.6-31.2(27.7) \pm 1.8$ & $27.3-30.6(29.0) \pm 0.8$ \\
\hline Distance between pectoral and pelvic-fin origins & 21.8 & $17.7-22.8(20.0) \pm 1.6$ & $18.3-22.2(20.0) \pm 1.4$ \\
\hline Distance between pelvic and anal-fin origins & 20.8 & $16.9-22.1(20.1) \pm 1.7$ & $16.9-21.7(19.6) \pm 1.5$ \\
\hline Dorsal fin depth & 18.3 & $15.2-20.6(17.8) \pm 1.5$ & $14.1-20.1(17.0) \pm 1.7$ \\
\hline Anal fin length & 19.4 & $17.6-25.0(21.3) \pm 2.1$ & $17.7-22.1(19.8) \pm 1.4$ \\
\hline Pectoral fin length & 15.6 & $13.7-19.1(16.3) \pm 1.6$ & $13.6-18.6(15.7) \pm 1.4$ \\
\hline Pelvic fin length & 20.5 & $17.5-23.0(20.1) \pm 1.4$ & $17.3-21.3(19.0) \pm 1.3$ \\
\hline Caudal peduncle length & 13.1 & $11.4-14.9(12.6) \pm 0.9$ & $12.7-14.9(13.5) \pm 0.6$ \\
\hline Caudal peduncle depth & & & \\
\hline In percent of head length & 29.4 & $26.5-32.9(29.6) \pm 1.9$ & $22.0-28.9(25.4) \pm 1.8$ \\
\hline Snout length & 22.6 & $22.0-25.9(24.5) \pm 1.4$ & $20.5-23.3(21.9) \pm 0.9$ \\
\hline Eye diameter & 38.3 & $34.6-40.5(38.2) \pm 1.6$ & $30.6-36.3(33.6) \pm 1.9$ \\
\hline Interorbital distance & 59.8 & $55.3-61.7(58.7) \pm 1.6$ & $53.8-63.2(58.0) \pm 2.8$ \\
\hline Head width at nape & 60.6 & $50.2-62.2(56.7) \pm 3.3$ & $49.7-58.2(53.7) \pm 2.6$ \\
\hline Head depth at interorbital region & 79.4 & $76.5-85.3(80.7) \pm 2.8$ & $70.8-80.7(74.9) \pm 1.5$ \\
\hline Head depth at nape & 42.0 & $40.0-48.8(43.4) \pm 2.3$ & $36.5-46.6(40.1) \pm 2.6$ \\
\hline Operculum depth & 36.0 & $32.6-38.6(35.5) \pm 1.2$ & $31.3-35.6(33.5) \pm 2.1$ \\
\hline Lower jaw length & & & \\
\hline & &
\end{tabular}

pared fins and caudal peduncle distinctly sexual dimorphic (male with longer pelvic and pectoral fins and slenderer caudal peduncle); lateral line incomplete, with 21-37 (commonly 26-37) perforated scales and 47-57+1-2 scales in lateral series (commonly $50-55) ; 10 \frac{1}{2}-12 \frac{1}{2}$ scale rows between lateral line and dorsal fin origin; 3-4 rarely 5 scale rows between lateral line and the pelvic fin origin; 7-8 (9) gill rakers on the first branchial arch; pharyngeal teeth $5-4$ or $5-5$, slightly serrated and hooked at tip; dorsal fin commonly with $7(8)^{1 / 2}$ branched rays; anal fin with $6(7)^{1 / 2}$ branched rays.

Description. See Figs 2-3 for general appearance and Tables 1-2 for morphometric and meristic data.

A Moderately deep-bodied, elongate and wide headed species. Dorsal profile of body slightly convex in predorsal area, ventral profile more convex than dorsal profile. Predorsal distance 52-57\% SL, mean 55.0 and preanal distance 69-74\% SL, mean 72.0. Head short, its length 26-28\% SL, mean 26.8, approximately 1.0-1.1 times body depth at dorsal-fin origin, and its dorsal profile slightly convex on snout. Head depth at interorbital region 2.1-2.7 times eye diameter and 1.3-1.6 times interorbital 
Table 2. Meristic features of the western Anatolian Pseudophoxinus species.

\begin{tabular}{l|c|c|c|c|c|c}
\hline Species & $\begin{array}{c}\text { Lateral } \\
\text { series }\end{array}$ & $\begin{array}{c}\text { Lateral } \\
\text { line }\end{array}$ & $\begin{array}{c}\text { Pharyngeal } \\
\text { teeth }\end{array}$ & $\begin{array}{c}\text { Total } \\
\text { vertebrae }\end{array}$ & $\begin{array}{c}\text { Abdominal } \\
\text { vertebrae }\end{array}$ & $\begin{array}{c}\text { Caudal } \\
\text { vertebrae }\end{array}$ \\
\hline P. alii & $41-44$ & $38-41$ & $5-5$ & $37-39$ & $21-23$ & $16-17$ \\
\hline P. antalyae & $52-64$ & $42-59$ & $5-5$ & $37-39$ & $20-22$ & $16-17$ \\
\hline P. anatolicus $(*)$ & $93-109$ & $78-93$ & $5-5$ & $41-42$ & $23-24$ & $17-18$ \\
\hline P. battalgilae $(* *)$ & $53-61$ & $53-60$ & $5-5$ & $37-38(39)$ & $20-21$ & $17-18$ \\
\hline P. burduricus sp.n. & $47-57$ & $21-39$ & $5-4(5)$ & $36-39$ & $21-22$ & $15-17$ \\
\hline P. crassus $(*)$ & $65-78$ & $62-73$ & $5-5$ & 40 & 22 & 18 \\
\hline P. elizavetea $(* *)$ & $60-68$ & $33-60$ & $5-5$ & $36-37(38)$ & 22 & $14-16$ \\
\hline P. evliyae & $52-66$ & $16-30$ & $5-4$ & $36-37$ & $21-22$ & $14-16$ \\
\hline P. hittitorum & $83-96$ & $83-94$ & $5-5$ & 39 & $21-22$ & $17-18$ \\
\hline P. maeandri & $41-45$ & $19-27$ & $5-4$ & $35-36$ & $19-20$ & $15-16$ \\
\hline P. maeandricus $(* *)$ & $66-67$ & $58-65$ & $5-5$ & $36-37$ & $20-21$ & 16 \\
\hline P. ninae & $46-53$ & $10-32$ & $5-4$ & 36 & 21 & 15 \\
\hline
\end{tabular}

${ }^{*}$ ) from Atalay 2005; (**) Bogutskaya et al. 2007

distance. Mouth slightly subterminal, posterior extremity of upper jaw slightly in front of anterior margin of eye. Snout rounded, its length 27-33\% HL, mean 29.6, greater than eye diameter. Caudal peduncle slightly deep, its depth 1.4-1.9, mean 1.6 times in its length.

Lateral line incomplete, usually reaching above anal fin origin, 32 perforated scales in the holotype (26-37 in paratypes), 47-57+1-2 scales in lateral series. Dorsal fin with 3 simple and $71 / 2\left(n=18\right.$, in one specimen $\left.8 \frac{1}{2}\right)$ branched rays, outer margin slightly convex. Anal fin with 3 simple and $6(15)^{1 / 2}$ or 7 (3) $1 / 2$ branched rays, outer margin slightly convex. Pectoral fin with 13-14 branched rays, outer margin straight or slightly convex. Pelvic-fin with 7 branched rays. Caudal fin forked, lobes rounded. There is no pelvic axillary lobe and keel between posterior pelvic fin base and anus. Pharyngeal teeth $5-4$ or $5-5$, slightly serrated, hooked at tip (developed on the left side). Gill rakers short and thick, with 7-8 (9) in outer side of first gill arch. Preoperculo-mandibular (CPM) and infraorbital (CIO) sensory canals disconnected, CSO with 10-12 pores, CIO with 14-19 pores, CPM with 14-18 pores, total vertebrae 36-39, 21-22 abdominal and 15-17 caudal vertebrae, vertebral formulae: 36-39:21-22+15-17.

Sexual dimorphism. In Değirmendere population, there is no tubercules on snout and head in males, which have longer pelvic and pectoral fins and slender caudal peduncles than females. In Lake Salda population, on the other hand, tubercules present in males on entire body (concentrated on operculum) and all fins except for the caudal fin.

Coloration. Body silvery, dorsal light brown or olive green and scales irregular with small epidermal spots in specimens larger than $50 \mathrm{~mm}$ SL. There is a faint epidermal black or violet (in Sazak population) stripe along lateral midline from eye to caudal fin base in alive. The dark stripe indistinct or slightly distinct in anterior part of body but distinct in posterior part of body in preserved specimens. Lateral line scales with 
small brown to black spots above and below pores in some individuals. Fin membranes whitish or light grey, rays with black-spotted. In individuals smaller than $50 \mathrm{~mm}$ SL: body silvery, dorsal dusty grey, ventral pearl grey.

Distribution. Pseudophoxinus burduricus is known only from the lakes and their sources in Lake Burdur Endorheic Basin: Değirmendere Creek, Lake Karataş, Düğer and Sazak (or Kümbet) springs, Dereköy Stream, Lake Salda and Salda Stream (Fig. 1). Değirmendere Creek is a $5 \mathrm{~km}$ long creek flowing into the Karamanlı reservoir, which is connected with artificial reservoir Lake Karataş. Düğer spring is a source of Lake Burdur, while Sazak Spring is a source of Lake Yarışl. Dereköy Stream is an approximately $5 \mathrm{~km}$ long rivulet formerly draining into Çorak (or Akgöl) Lake which, due to a small reservoir constructed in 1970, no more can reach the lake. The new species can be encountered in the shallow parts of the reservoir and the small stream flowing into it.

Other species present were: Chondrostoma fahirae (Ladiges, 1960), Oxynoemacheilus anatolicus Erk'akan, Özeren \& Nalbant, 2008 and Oncorhynchus mykiss (Walbaum, 1792) (an escape from fish farms in Karamanlı reservoir) in Değirmendere, in Düğer Spring only O. anatolicus and in Salda Stream only Aphanius splendens (Kosswig \& Sözer 1945).

Etymology. The species is named after the Burdur Province where the type locality is located.

\section{Discussion}

Hrbek et al. (2004) stated that monophly of Anatolian Pseudophoxinus taxa was not well supported and these represented 6 distinct clades. Of these, Lakes Region populations (Lakes Salda and Karataş, Düğer Spring, Karapınar) identified as P. maeandri formed Clade IV, while the Avlan and Kırkpınar populations identified as P. fahirae (now $P$. evliyae) formed a separate clade (Clade VI). Perea et al. (2010) mentioned of two well defined monophyletic groups within Anatolian Pseudophoxinus taxa, though not discussion interrelationships of these two. A phylogenetic tree based on the cytb gene sequence, Hrbek et al. (2004: 299) showed presence of two different clade; (I) Lake Avlan and Kırkpınar (Lake Söğüt source) populations (P. evliyae) and (II) populations from Burdur and Salda basins.

In this study, we also morphologically compared the new species with Pseudophoxinus ninae (the Onaç Stream and Kestel Swamp), P. evliyae (dried Lake Söğüt [Kırkpınar Village, Korkuteli] and source of Lake Avlan [Elmalı]), P. maeandri [Lake Işıklı], P. maeandricus (Karadirek Stream [Upper Büyük Menderes basin]), P. alii (Köprüçay and Ilıca Stream), P.battalgilae (Manavgat River basin, Lake Akgöl [Ereğli], Lake Çavuşcu [Ilgın] and Lake Suğla [Seydişehir]), P. fahrettini (Köprüçay River basin [Bağıllı Village and Değirmenözü Stream]), P. antalyae (Kırkgöz Spring, Karamanlı Stream and tributaries of Düden canal in Antalya), and P. elizavetae (Sultansazlığı [Kayseri]).

Pseudophoxinus burduricus is most similar to P. ninae (Fig. 4). It is distinguished from $P$. ninae by having fewer branched pelvic fin rays $(7$, vs. 8 or 9$)$, slightly fewer 


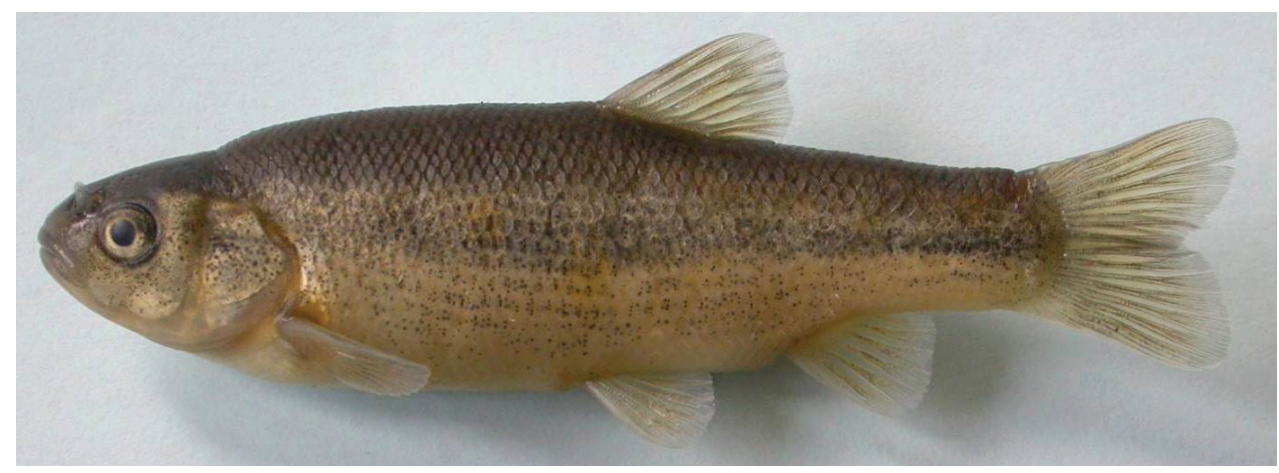

Figure 4. $P$. ninae IFC-ESUF 0263, 66.37 mm SL; Turkey: Pınargözü Spring-Bucak.
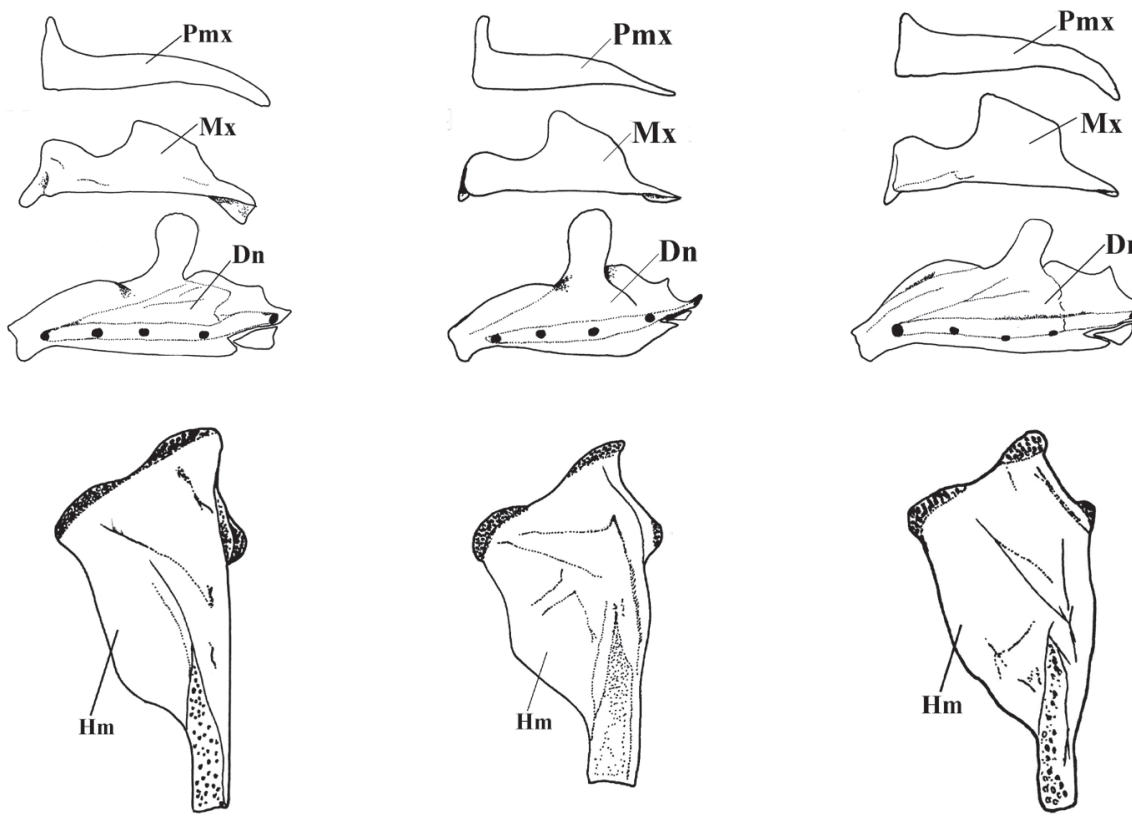

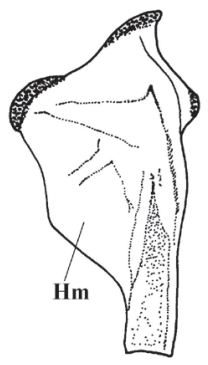

b
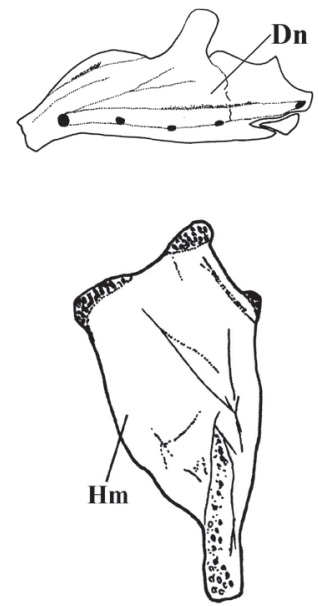

c

Figure 5. Left jaws and hyomandibular bones of P. burduricus sp. n. (a) P. ninae (b) and P. maeandri (c) (Pmx: premaxilla, Mx: maxilla, Dn: Dentale, Hm: Hyomandibulare)

gill rakers in outer side of the first gill arch (7-8, rarely 9, vs. 8-9) and a longer caudal peduncle (caudal peduncle length 1.4-1.9 times caudal peduncle, vs. 1.3-1.4). It further differs from $P$. ninae by having a shorter predorsal distance $(52-57 \% \mathrm{SL}$, mean 55.0 , vs. 57-61, mean 58.0), a shorter preanal distance (69-74\% SL, mean 72.0 , vs. 73-77, mean 74.5), a somewhat shorter head (head length 26-28 \% SL, mean 26.8, vs. 27-31, mean 28.6), and narrower and relatively deeper hyomandibular bone (vs. wide and shallow) (see Figs 5a, b, c). Also Pseudophoxinus burduricus and P. ninae were compared by Principal Component Analysis (PCA). The PCA was performed in us- 


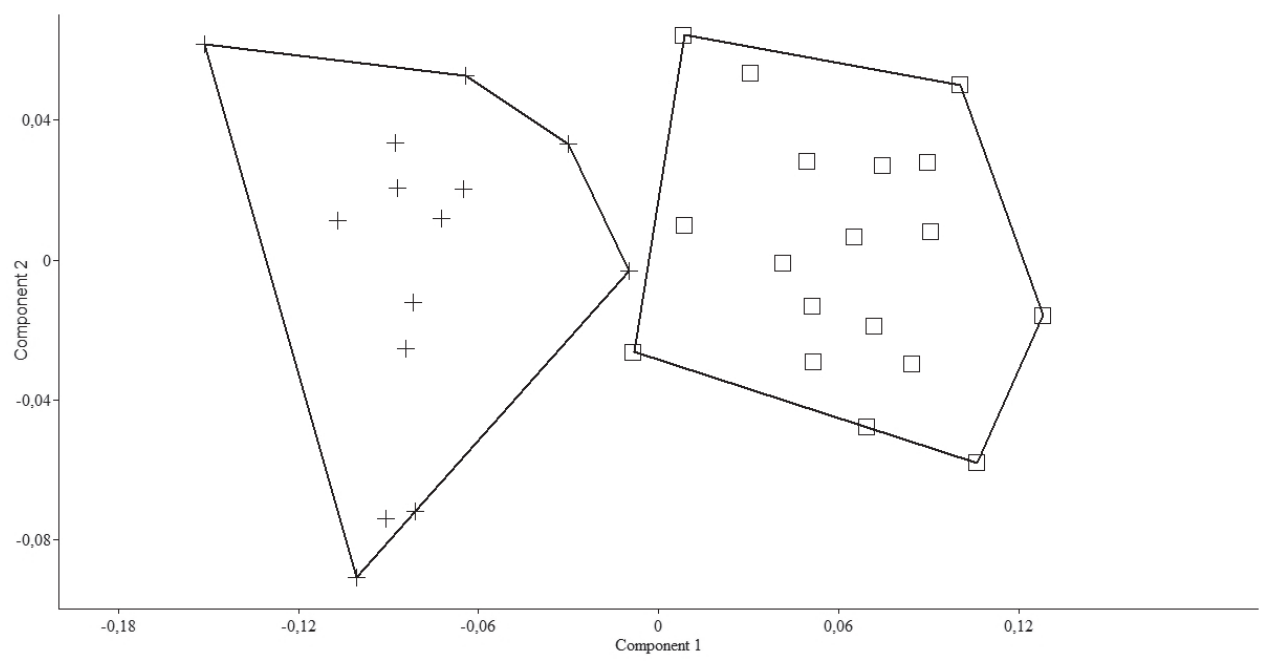

Figure 6. A scatter plot of the scores of the first two principal components (PC I, PC II) for 32 specimens of the two Pseudophoxinus species (P. burduricus sp. n. (+) and P. ninae (口), based on 18 morphometric characters.

ing 18 morphometric characters of the two Pseudophoxinus species. The PCA clearly separated Pseudophoxinus burduricus from P. ninae (Fig. 6). Variables loading on the first metric PC I-II are given in Table 3.

Pseudophoxinus burduricus is distinguished from $P$. evliyae by having fewer scales in lateral series $(47-57+1-2$, vs. 54-64+1-2), fewer branched pelvic fin rays (7, vs. 8), fewer gill rakers in outer side of first gill arch (7-8, rarely 9, vs. 8-9 to 10 in some specimens), fewer scales between lateral line and dorsal fin origin $\left(10^{1 / 2}-12 \frac{1}{2}\right.$, vs. $131 / 2$ $15 \frac{1}{2}$ ), and a faint epidermal black or violet stripe along lateral midline from eye to caudal fin base (vs. black prominent stripe). Pseudophoxinus burduricus is distinguished from $P$. maeandri by having more lateral line and lateral series scales (21-39, vs. 19-27 and 47-57+1-2, vs. 40-44+1-2 respectively), more total vertebrae, 36-39 (vs. 35-36) (see Table 2). Pseudophoxinus burduricus differs from P. maeandricus by having an incomplete lateral line (vs. complete), a shorter pelvic-fin (reaching to anus, vs. not reaching), wider and deeper head (head width at nape 55-62 \% HL, vs. 46-48; head depth at nape 77-85\% HL, vs. 67-73). Pseudophoxinus burduricus is distinguished from $P$. alii by having more scales in the lateral series $(47-57+1-2$, vs. $38-43+1-2)$, fewer perforated scales (21-39, vs. 38-41) and smaller eyes (eye diameter 22-26\% HL, vs. 26-32). Pseudophoxinus burduricus is distinguished P. antalyae by presence of a faint black or violet lateral stripe (vs. plain golden or orange stripe when alive), rounded snout (vs. pointed) and shorter pharyngeal teeth. Pseudophoxinus burduricus is distinguished from $P$. battalgilae by an incomplete lateral line (vs. complete), fewer gill rakers in outer side of first gill arch (7-8, rarely 9, vs. 13-16), fewer branched anal fin rays $(6-7$, vs. 8 , respectively), and the absence of a keel between the pelvic fin base and the anus (vs. presence). Pseudophoxinus burduricus is distinguished P. fahrettini by an incomplete lateral line (vs. complete), fewer perforated scales lateral line (21-39, vs. 
Table 3. Character loading on principal components I-II for 18 measurements taken on 32 specimen of two Pseudophoxinus species (P. burduricus sp.n. and P. ninae).

\begin{tabular}{l|c|c}
\hline \multicolumn{3}{c}{ Morphometric features } \\
\hline In percent of standard length & PC I & PC II \\
\hline Head length & 0.196 & -0.103 \\
\hline Body depth of dorsal-fin origin & 0.335 & 0.222 \\
\hline Predorsal length & 0.140 & 0.119 \\
\hline Prepelvic length & 0.147 & 0.145 \\
\hline Preanal length & 0.083 & 0.156 \\
\hline Dist. from pectoral-fin origin to anal fin & 0.060 & 0.331 \\
\hline Dist. from pectoral-fin origin to pelvic fin & 0.140 & 0.396 \\
\hline Dist. from pelvic-fin origin to anal fin & 0.012 & 0.368 \\
\hline Length of caudal peduncle & -0.300 & -0.383 \\
\hline Depth of caudal peduncle & 0.180 & 0.112 \\
\hline In percent of head length & & \\
\hline Snout length & -0.445 & 0.322 \\
\hline Eye diameter & -0.285 & -0.118 \\
\hline Interorbital distance & -0.420 & 0.166 \\
\hline Head width (at operculum) & -0.054 & 0.300 \\
\hline Head depth (at interorbital region) & -0.202 & 0.080 \\
\hline Operculum depth & -0.290 & 0.155 \\
\hline Head depth operculum & -0.208 & 0.164 \\
\hline Length of lower jaw & -0.172 & 0.164 \\
\hline
\end{tabular}

73-88) and fewer gill rakers in outer side of first gill arch (7-8, rarely 9, vs. 11-13). Pseudophoxinus burduricus is distinguished $P$. elizavetae by having fewer scales in the lateral series (47-57+1-2, vs. 56-62+2-3), fewer gill rakers in outer side of first gill arch (7-8, rarely 9, vs. 11-13).

\section{Comparative material (all from Turkey)}

Pseudophoxinus alii: IFC-ESUF 0169, 13 paratyps, 53.33-98.48 mm SL; Antalya Prov.: Ilıca Stream at Manavgat, F. Küçük, 05 May1996.

Pseudophoxinus antalyae: IFC-ESUF 0159, 10, 64.07-97.10 mm SL; Antalya Prov.: Düden Canal, W.V.Neer, F. Küçük, R.Wildekamp, M. Ünlüsayın, 28 July 1996. Pseudophoxinus battalgilae: IFC-ESUF 0161, 18, 46.51-109.68 mm SL; Antalya Prov.: Oymapınar Dam Lake at Manavgat, F. Küçük, 05 May 1996.

Pseudophoxinus elizavetae: IFC-ESUF 0174b, 10, 49.29-67.47 SL; Kayseri Prov.: Sultansazlığı, M.A. Atalay, 23 August 2004.

Pseudophoxinus evliyae: IFC-ESUF 0237, 26, 25.38-57.51 SL; Antalya Prov.: Kırkpınar-Korkuteli, F. Küçük, İ. Gülle, 10 May 1998. IFC-ESUF 0269, 10, 26.17-66.92 mm SL; Antalya Prov.: Kırkpınar-Korkuteli, F. Küçük, T. Şahan, 
25 May 2007.- IFC-ESUF 0268, 1, 73.39 mm SL; Antalya Prov.: Kazanpınar1-

Elmalı, F. Küçük, T. Şahan, 25 May 2007.

Pseudophoxinus maeandri: IFC-ESUF 0248, 8, 46.70-55.96 mm SL; Denizli Prov.: Lake

Işıklı source, F. Küçük, M.A. Atalay, N. Bogutskaya \& A.Naseka, 14 August 2006.

Pseudophoxinus maeandricus: 3, 60.71-78.70 mm SL; Afyon Prov.: Karadirek Stream-

Sandiklı, V. Yeğen, 29 June 2006.

Pseudophoxinus ninae: IFC-ESUF 0263, 4, 48.9-67.5 mm SL; Burdur Prov.: Pınargözü-

Bucak, F. Küçük, T. Şahan, 25 May 2007. -IUSHM 33900-928, 15, 46.4-68.4

mm SL; Burdur Prov.: Onaç Stream, M. Özuluğ, J. Freyhof, 12 June 2006.

\section{Acknowledgments}

This study was supported by the Research Fund of Süleyman Demirel University (grant SDÜ-08.M.1354). The authors thank to Dr. M. Özuluğ (İstanbul Üniversity) and V. Yeğen (Ministry of Food, Agriculture and Livestock) for donating some fish specimens, and Dr. Davut Turan (Recep Tayyip Erdoğan University) and three anonymous reviewers for commenting on earlier versions of the manuscript.

\section{References}

Atalay MA (2005) Pseudophoxinus (Pisces, Cyprinidae) Genusu'nun Anadolu'da Yayılışı ve Taksonomik Özelliklerinin Belirlenmesi (Distribution of the genus Pseudophoxinus (Pisces, Cyprinidae) in Anatolia and Determination of its Taxonomic Features. PhD thesis, Isparta, Turkey: Süleyman Demirel University). [In Turkish]

Bogutskaya NG (1992) A revision of species of the genus Pseudophoxinus (Leuciscinae, Cyprinidae) from Asia Minor. Mitteilungen aus dem Hamburgischen Zoologischen Museum und Institut 89: 261-290.

Bogutskaya NG (1996) Contribution to the knowledge of leuciscine fishes of Asia Minor. Part 1. Morphology and taxonomic relationships of Leuciscus borysthenicus (Kessler), Leuciscus smyrnaeus Boulenger and Ladigoesocypris ghigii (Gianferrari) (Cyprinidae,Pisces). Publ. espec. Inst. Esp. Oceanogr. 21: 25-44.

Bogutskaya NG, Küçük F, Atalay MA (2007) A description of three new species of the genus Pseudophoxinus from Turkey (Teleostei: Cyprinidae: Leuciscinae). Zoosystematica Rossica 15: 335-341.

Freyhof J, Özuluğ M (2009) Pseudophoxinus evliyae, a new species of spring minnow from Western Anatolia with remarks on the distribution of $P$. ninae and the systematic position of $P$. fahirae (Teleostei: Cyprinidae). Ichthyological Exploration of Freshwaters 20: 309-318.

Hammer O, Harper DAT, Ryan PD (2001) PAST: paleontological statistics software package for education and data analysis, Palaeontologia Electronica 4: 9.

Hrbek T, Küçük F, Frickey T, Stölting KN, Wildekamp RH, Meyer A (2002) Molecular phylogeny and historical biogeography of the Aphanius (Pisces, Cyprinodontiformes) species 
complex of central Anatolia, Turkey. Molecular Phylogenetics and Evolution 25: 125-137. doi: 10.1016/S1055-7903(02)00203-8

Hrbek T, Stölting KN, Bardakçı F, Küçük F, Wildekamp RH, Meyer A (2004) Plate tectonics and biogeographical patterns of the Pseudophoxinus (Pisces: Cypriniformes) species complex of central Anatolia, Turkey. Molecular Phylogenetics and Evolution 32: 297-308. doi: 10.1016/j.ympev.2003.12.017

Kottelat M, Freyhof J (2007) Handbook of European freshwater fishes. Kottelat, Cornol and Freyhof, Berlin, xiv + 646 pp.

Ladiges W (1960) Süsswasserfische der Turkey 1. Teil Cyprinidae. Mitteilungen aus dem Hamburgischen Zoologischen Museum und Institut 58: 105-150.

Naseka AM (1996) Comparative study on vertebral column in the Gobioninae (Cyprinidae, Pisces) with special reference to its systematics. Esp. Oceanogr. 21: 149-167.

Perea S, Bohme M, Zupancic P, Freyhof J, Sanda R, Özulug M, Abdoli A, Doadrio I (2010) Phylogenetic relationships and biogeographical patterns in Circum-Mediterranean Subfamily Leuciscinae (Teleostei, Cyprinidae) inferred from both mitochondrial and nuclear data. BMC Evol. Biol. 10 (1): 265. doi: 10.1186/1471-2148-10-265 